\title{
'Old Lady Mob': Interview
}

\section{Christine Nicholls and Kathleen Petyarre}

Kathleen (born Kweyetemp) Petyarre, one of Australia's foremost living Indigenous artists, was born between 1931 and 1940 on her family's vast desert estate, Atnangker, located almost three hundred kilometres north east of Alice Springs in arid, spinifex country. Petyarre, an Eastern Anmatyerr woman, saw a white man for the first time when she was around eight or nine years old. Hiding behind a group of small bushes, Petyarre and her siblings reported their 'discovery' of the strangely coloured man to their father, Kngwarreye, who tentatively approached the man, generously offering him life-giving water and delicious bush food.

Since that fateful day, Kathleen Petyarre has been fascinated by the machinations of white people and their society. When adult educator Jenny Green arrived at Utopia in the late 1970 , Petyarre eagerly joined in batik classes. Kathleen Petyarre has gone on to achieve considerable national and international celebrity as a visual artist.

Christine Nicholls spoke with Kathleen Petyarre in September 2004, when she met Kathleen with her sisters Myrtle and Violet, to talk about new work that was exhibited as part of the 'Body Painting Series', at the Coo-ee Gallery, Sydney, opening on 11 November 2004, in an exhibition titled 'Arnkerrth: Kathleen Petyarre, Abie Loy'. Christine spoke again with Kathleen in December 2004 (with Penny Hoile of Gallerie Australis, which represents Kathleen) specifically for the 2004 special issue of Cultural Studies Review on Indigenous art. Kathleen was asked about aspects of her work discussed at the symposium 'Mountain Devil Lizard Dreaming' held at the University of Tasmania in March 2003, to which she had been invited but had been unable to attend. 


\section{September 2004}

Christine Nicholls: Kathleen, what can you tell me about your new body of work, about these new paintings?

Kathleen Petyarre: These paintings are our Arnkerrth (Mountain Devil Lizard) body painting from the old days, when we would paint up our bodies and dance - they are paintings about our body designs from those old days. We used yellow and white ochre. We put them on our skin, on top of red ochre body paint. We also had black. We used little sticks - tyepal - to paint that ochre on our bodies.

Christine Nicholls: What makes you want to paint these works?

Kathleen Petyarre: I've been thinking a lot about those old days and how we used to put that body paint on ourselves. I've been thinking back a lot, how we don't do it now. The last time we really did this body painting and dancing and singing was when we went to Sydney long time ago for a land rights meeting: all the Petyarre mob-Myrtle, Gloria, me-Auntie Emily Kngwarreye, Rosie Kngwarreye, Lena Skinner and all the Pitjantjatjara and other mob.

Christine Nicholls: Are you able to say any more about the ceremonies that inspired these paintings?

Kathleen Petyarre: This body painting (that is, in Kathleen's recent work) is for women-only ceremony. It's painted on our stomachs and thighs like an apron - in those days (we wore) no pants on our back or front side, just naked, naked backsides. (Laughing) Naked! There's (a) string belt, and underneath was the ochre paint. The ochre paint goes half way up (our bodies) - from knees up to waist. We wore hairstring belts around our middles, with strings hanging down over black, white and mainly yellow ochre paint underneath. This is really Old Law for Anmatyerr dancing ladies, not for men.

Auntie Emily Kngwarreye and my big sister Myrtle gave this ceremony and body painting to the rest of us. 
Christine Nicholls: Were all age groups, young girls and older women, involved in these ceremonies?

Kathleen Petyarre: This one is for grown-up women, not for little kids or little girls. We don't do it now, any more. We put on Arnkerrth (Mountain Devil) paint designs - my big sister Myrtle is the boss for that. It's part of the awelye ceremonies - not love ceremony, that's different one. It's Arnkerrth (Mountain Devil) Dreaming body paint and dance ceremony, only for grown-up women.

Christine Nicholls: Can you remember the first time that you saw Anmatyerr ladies doing these dancing and painting-up ceremonies?

Kathleen Petyarre: When we were little kids, we'd see all the Old Lady mob do these Mountain Devil dances with the body paint. We'd watch them all painting up, then dancing, Myrtle and me. We would be hiding behind the trees, looking, and sometimes, copying. We would follow all the Old Lady mob, me and Myrtle, while they did these dances in those old days. We'd follow our Grandmother and Mother mob doing these dances in the old days.

It's a proper important thing, following this ceremony, this dancing. Dancing, dancing, big clouds of dust and earth would rise up from ground when all that Old Lady mob would be dancing.

Christine Nicholls: Did all of you girls, all the sisters, like watching at the Old Ladies dancing?

Kathleen Petyarre: Me and Myrtle, we'd watch'em and follow'em with our little billy can and our little swag. We'd get witchetty grub, little lizards and goannas, cookem and eat'em and follow that Old Lady Grandmother mob when they did the ceremony dancing.

We loved copying those old ladies in those old days. While we were standing hiding behind the trees! When they couldn't see us! We'd hide, and copy the old ladies dancing, like this (Kathleen and Myrtle demonstrate, amidst peals of laughter) 
standing behind the trees, and when they caught us copying them, Grandmother would call out, 'Go back you mob!' Grandmother'd yell out, 'You're too little! You're too little to do this dancing! Go away you mob!'

Kathleen Petyarre: This is still the Mountain Devil painting, still part of Anmatyerr women's ceremonies. It's white because the hail has been coming down in big white iceblocks, around Christmas time. The hail covers Atnangker, Arnkerrth the Mountain Devil Lizard's country, we mob's country, my country. But it's not Hail or Rain Dreaming - no way, it's Mountain Devil Dreaming, country, ceremony. The important thing in this picture is it's Mountain Devil ceremony, Mountain Devil Dreaming and Mountain Devil country. It shows where Arnkerrth that Old Lady Mountain Devil is dancing by herself, travelling around Atnangker, sometimes travelling alone, sometimes coming back to her country Atnangker - that's the country belonging to Mountain Devil, this is all coming from ceremony. In the old days we would often usem white $n g u n j a$ ngunja and smash up little rocks, mixem up with water, for body painting, to show this Dreaming. Same way we would paint this on to our legs or use as body painting on the top part of our bodies - usem same colour, same design. White, red, yellow. No black. White is ajulkwa, important thing here on this painting.

When we were painted up our legs and bodies we looked like we wearing little aprons ngajalarra - the leg paints looked like little skirts or little pants. Not now-we wear petticoats and skirts for this ceremony. Not now-finished. We just do paintings on canvas now, but same ceremony, same story.

Violet Petyarre: My paintings that you see here are all part of the Anmatyerr women's ceremonies-awelye. Especially, they are about the dances for Arnkerrth, the Mountain Devil Dreaming. They show the way that she, that Old Lady Mountain Devil, walks around our country, with all the little ones too, the little mountain devils who walk around with that Old Lady, looking around for ants, because they've got to eat something, walking around every place round our country, following the Old Boss Lady Mountain Devil, Arnkerrth. In 
the old days we painted these designs with little sticks onto our chests - we were naked and putting these designs on was like putting on clothes. These designs are like clothes for us. Some of these designs were painted on to this part of our legs too (indicating her thighs). Another mob would be singing the Arnkerrth songs (while we painted them onto our upper bodies) and another mob would be dancing, but it was all one ceremony for sure. Those dances took a long time in the olden times - that old lady, auntie for me, that old Emily poor thing, she'd take on all of these ceremonies.

In the old days we only used red colours, white ones and yellow - no blue, no purple, but now we use canvas we can use any colour - that's what you see here! That's enough kwiakulai-I've finished.

\section{December 2004}

Christine Nicholls: So, what goes through your head while you are painting your art works? What do you think about while you paint your Mountain Devil paintings?

Kathleen Petyarre: Well, in my head is my memory of a long time ago in the bush, my grandmother teaching me, the old ladies dancing a big ceremony, and me just watching when I was a little girl, and then later, when I was still a little girl, but a bit bigger, I was joining in the dancing too. That always goes around in my head when I paint my work. Myrtle, Nancy, Violet, me, we were little when we started, and we learned. We all know that olden-time dancing, learning when we were little - that's what's in my memory when I paint. My grandmother would decide when it was time for the Mountain Devil ceremony to be performed - and two women would be standing around with nulla nullas, and stick them right down into the sand. The women would paint the nulla nullas first, white, red and yellow ochres, and black, they are the colours of the mountain devils and they show how the mountain devils change colours. Then the old women would wait and grab a mountain devil and start to sing and wait and watch for that mountain devil to change colour. We grabbed, we looked, we waited until we saw her (the actual live mountain devil) 
change colour, and then when she was changing colour all the time, we'd let her go then, and then the ceremony would start. That's the big Law - we were only allowed to start that ceremony once the mountain devil had changed her colour.

We'd begin by carrying bags of red ochre on our backs from Atnangker, to start that ceremony. Once she'd changed colour and we'd let her go we'd start the singing and clapping properly. It would happen round about the hot time every year but before rain time - and we would always perform the Mountain Devil Arnkerrth ceremony three times, late in the afternoon, then at night, then (at) knock off time or teatime. One old lady would dance the Mountain Devil part, that woman would always be my grandmother. Grandmother would put that pattern into the sand, and when I was little I'd be calling out, 'I want to learn', and I would go in and try to change it, change that pattern in the sand, and Grandmother would chase me away. Grandmother would yell out, 'Go back! Go back you little girl, you're only a little girl, go back!' And I would say, 'I want to learn Grandmother, Grandmother, I want learn, so that I can take up that law for the family, so I can carry that law, when you pass away.'

The other women would be singing and another mob would be painting up with little sticks, painting here first (indicating upper arms and making a sweeping movement across them) across like that (indicating horizontal axis), from the upper arms and across and down the chest then down their chest, then painting down the titties, going this way (indicating vertical axis), then straight down the thighs (indicating vertical axis again with a sweep of her hands simulating painting), then when we were fully painted up, then we girls and young women and old women would put on our hairstring belts, and headbands, made with hairstring and cocky feathers. It was for the girls' initiation ceremonies we did this and they are very secret and I can't say more.

Afterwards, after the ceremony, we would eat a lot of food-kangaroo, goanna, perentie and rabbit.

Christine Nicholls: One of the members of the group involved with this conference and the book, Jennifer Biddle, I think, has written that there is a lot in your work about 
breasts and fertility - can you comment on that, please?

Kathleen Petyarre: True.

Christine Nicholls: Are you able to say more?

Kathleen Petyarre: No. True, it's true, but I won't say more. Not a word. Secret.

\section{Reflection}

By way of reflection I offer previously unpublished interviews with Kathleen Petyarre on the subject of time, and the passing of time. These interviews were conducted on 1 October 2008 in Melbourne and continued on 7 October 2008 in Adelaide.

Christine Nicholls: Kathleen, as we've discussed, we're going to talk about time. Would you like to start by talking about the happiest times of your life?

Kathleen Petyarre: It was happiest time of my life when I was growing up as little kid, out longa bush with my father at Atnangker. In those days nobody humbugged, my father was there, my mother was there, mother was smarter, nobody humbugged or teased me [because] my mother was smart and stopped 'em - that's why I am smart myself, because of my mother.

My grandfather and grandmother bin grow me up too-I really loved them. I just followed them, I loved follow[ing] them, then after little while, I'd go back [to my] father, go back [to my] mother.

Now looking back I know I was happy because I was with my family all the time and because we stayed close.

Today, so many alcoholic[s], so many violent [people], fight over nothing, not like early times, old times, when no one ever humbugged for me or for anyone. Nowday I try to stop humbug-I tell them off all the time, I say, 'You fellas go and drink somewhere else!' But it's hard, hard in my life now.

Different then.

Those time. Old days.

I loved my country, I loved going round with all my family, all my sisters, looking for bush tucker. It was early days, long time ago. It seems like a dream, those early days. But Altyerr [Dreaming] goes 
on today, still the same.

When I look back on those days my happiest time[s] [were] when I ran around that spinifex country carrying my yam stick and my firestick. I really loved that spinifex country-I bin go all over that spinifex country looking for goanna.

Christine Nicholls: Were there any hard or difficult times when you were younger?

Kathleen Petyarre: I really didn't want promised husband, old man. I was married a long time ago, when I was young girl. Teenager. It wasn't happy time.

Only one good happy thing happen then. My father, Kngwarreye, you know, he was brother for Aunty Emily [Kngwarreye], same father different mother, my father decided to pass me down the Arnkerrth [Mountain or Thorny Devil] Dreaming. Chose me. So he gave it to me-big Dreaming, big story, painting. Said I'm the only one who can know the whole thing, story, painting - from all the sisters and brothers. So all the sisters are allow paint awely [women's body painting, ceremonies and rituals] and brothers could paint other things, but only I could paint whole lot of our country AtnangkerArnkerrth [Mountain or Thorny Devil] country. So I'm only one doing that whole country now.

Later my daughter was born Amaroo, after my promised husband passed away. Margaret's father was government man, white man, worked for Amaroo Station, looked after all the bulls. Worked for the government. Nice bloke. We didn't get married. Just friends.

Christine Nicholls: When you think about those old times, do you feel like you are now a different person?

Kathleen Petyarre: Yesterday, when I was lying in bed worrying for everything my mother came [to] me in a dream - her spirit comes to me all the time when I feel depress, sad, because of all the humbug today, because of all the drunks [in] the family nowday. So different from those old times. Healthy then. My mother come[s] to me as spirit and she says like questions 'Mwerr?' [Are you well, healthy, good?] 'My daughter, you're mwerr, you're all right? You right?' And I say, 'Mother, Mum, I'm ok, mwerr'... She say 'Kel mwerr'. [Ok, that's good!] And Dad too, Dad he come sometime and see me. 
Visit. So those old [days or times] haven't disappeared. Long, long time ago [those] early days, but still with me now, but still, still happening now. Right now. Those old people are with me. All the time. My mother was Rain Dreaming - that was her country. When it rain, him [she] follow the rain, him [her] spirit follow the rain, that's when him [her] spirit come to me, when it rain. My father and mother, I go back and see them when I want to. I'm a ngangker, witch doctor, [traditional healer], can do clever things, so can move back to past time then back again to now-time. Move between. Can move between time of then and now, nowday and then. I sometimes see my two uncles too.

Christine Nicholls: Is there anything else you'd like to say about time? What if you could make a wish about time?

Kathleen Petyarre: But if I could make wish I like to move straight back into them old days out in spinifex country-good. Life good then-all the time.

Christine Nicholls: Is there anything else, about time, in the past, present or future, before we finish?

Kathleen Petyarre: I want to pass on my Arnkerrth Dreaming before I finish up - one of my grandsons might be the one to carry [it] forward. Not drinking, him. I'm beginning to teach him painting now. He wants to learn. Carry forward. I hope. 